Journal of English Language Teaching and Applied Linguistics

ISSN: 2707-756X

DOI: $10.32996 /$ jeltal

Journal Homepage: www.al-kindipublisher.com/index.php/jeltal

JELTAL

\title{
An Investigation into Ho Chi Minh City University of Food Industry students' Satisfaction of Online Learning
}

\author{
Ngô Thị Ngọc Hạnh 8 (D) \\ Faculty of Foreign Languages - Ho Chi Minh City University of Food Industry, Vietnam \\ $\square$ Corresponding Author: Ngô Thị Ngọc Hạnh, E-mail: bachtrunghanh9@gmail.com
}

\section{ARTICLE INFORMATION}

Received: May 04, 2021

Accepted: June 01, 2021

Volume: 3

Issue: 6

DOI: 10.32996/jeltal.2021.3.6.13

\section{KEYWORDS}

Online learning, satisfaction, internet, students, teachers

\section{ABSTRACT}

This paper aims to analyse the level of Ho Chi Minh City University of Food Industry $(\mathrm{HUFI})$ satisfaction with the online learning approach and learning experiences during the COVID-19 widespread in Viet Nam. Qualitative research was carried out using online interviews of students from different subjects. The following four research questions were addressed: (1) Have you ever experienced studying online? (2) Do you like studying online? (3) What factors cause the obstacles of studying online? And (4) What do you expect from your online teachers? The results showed that the majority of students were dissatisfied with the current methodology. They suffered from a poor Internet connection, surroundings, a loss of self-awareness, lack of interaction and feedback, and philosophical lectures. Furthermore, they expected exciting e-learning lesson plans and their teachers' sense of humour. More analysis is required to incorporate career development workshops and practical training courses into online learning and teaching, according to this report, to support creative teaching methods and effective ways for students in a new platform.

\section{Introduction}

Corona Virus, also known as Covid-19, is a lethal and contagious disease that has had a significant impact on the global economy. This tragedy has already rocked the education system, and this panic is expected to spread across the world's education sector. The Covid-19 pandemic caused several schools and colleges to close temporarily. Several fields are affected globally, and there is concern that the next semester and upcoming semesters will be lost. In-person instruction has been phased out at several schools, colleges, and universities. According to the experts, it is unlikely that regular teaching will resume anytime soon. Institutions in higher learning are struggling to find solutions to this complex challenge. Social separating is the cognizant increase within the physical gap between individuals to control the spread of infection (Red Cross, 2020). This is a condition that necessitates humanity and cooperation. Our students, professors, academic personnel, community, society, and the country as a whole all need to be protected and saved. To deal with this real situation, the online learning approach is compelled to apply widespread. Online learning is the utilize of the web and a few other imperative advances to create materials for informational purposes, guidelines conveyance and administration of the program (Fry,2001). It is said that the online mode of learning is effectively open and can indeed reach to country and farther ranges. It is considered a moderately cheaper mode of instruction in terms of the lower fetched of transportation, settlement, and the general fetched of institution-based learning. Take after the common trend of the world, Ho Chi Minh City University of Food Industry (HUFI) has operated online learning on Zoom program for the total understudies since 2020 with different subjects. Numerous students have experienced opportunities and challenges with the online platform. In this article, the analyst wanted to dissect the satisfaction of the learners at HUFI to discover the best solution to make the online platform progressively successful and charming.

\section{Literature Review}

McBrien (2009) claimed that fast advancements in innovation have made separate education simple. Online learning can be named as a gadget that can make the teaching-learning gets ready more student-centred, more creative, and without a doubt, more versatile. Online learning is characterized as "learning experiences in synchronous or asynchronous environments utilizing

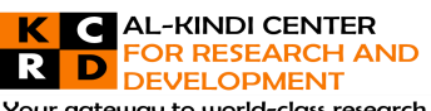

Your gateway to world-class research



Published by Al-Kindi Center for Research and Development, United Kingdom. Copyright (c) the author(s). This open access article is distributed under a Creative Commons Attribution (CC-BY) 4.0 license 
unmistakable devices such as smartphones and laptops with internet access. Singh, Malik and Singh (2016) stated that students are more likely to enrol in a program if their online experiences are positive, according to Kransow (2013). A fundamental concern for instructors working in an online context, according to Kransow (2013). How might online courses be designed to increase understudy satisfaction, motivation, inspiration, and diligence? Taking advantage of according to Kransow (2013), students are more inclined to enrol in a program if their online experiences have been pleasant. A fundamental concern for instructors working in an online context, according to Kransow (2013). Be that as it may, building an online community that develops understudy fulfilment includes methods that go past empowering interaction with course components. Interaction between understudies and instructors and interaction among understudies inside the course are all necessary components of forming a community. Palmer and Holt (2009) revealed that a student's comfort level with progress was critical to their performance in online courses. The student's self-evaluation of how well they were performing in the online setting was one of the assistant components. Positive perceptions of innovation were also one of two major aspects of understudy satisfaction, according to Drennan, Kennedy, and Pisarski (2005). The topic of the minute was learning methods of independence and inventiveness. Richardson and Swan (2003) investigated the link between social proximity and educator satisfaction in online learning. They discovered a link between students' recognition of learning and enjoyment and their perceptions of social proximity. Online learning represents a significant shift in how individuals learn and, as a result, how students are educated. The argument is stated that there is a growing need to receive it, which leads to understudy fulfilment with online learning (Sinclaire, 2011). In addition to the organization components that Abel (2005) recorded in his essay on best sharpens, understudy happiness is one of a few elements affecting the success of online learning programs (administration, workforce commitment, understudy back, and innovation). Sener and Humbert (2003) kept up that satisfaction may be a significant component in making a productive online program. Kleinman (2005) investigated how to improve the instructional architecture of online courses to optimize constructive learning and engagement. Kleinman researched online learning communities for ten years and concluded that an online community that fosters productive involved learning and offers the engaging resources needed to help students understand what has anticipated leads to happy learners. To properly test student satisfaction, Wang (2003) concluded that researchers must first determine the feasibility of online education.

\section{Methodology}

The participants in this sample were ten students who completed two semesters of online learning in various subjects. The writer collected data by interviews after online classes. All the interviews took place in the ninth week of the second semester in 2021 when the students suffered nearly two years of Covid pandemic. The writer's point of view was not put on the participants through the surveys. The interviewees openly shared their interactions with the online forum and offered some valuable ideas for a more effective solution. The responses to the questions were entirely voluntary. The researcher conducted interviews in some classrooms at random using Zoom, an online classroom program. The outcomes were meticulously recorded.

\section{Results and Discussion}

\subsection{Findings for the RQ 1: Have you ever experienced studying online?}

Students at HUFI have recently become acquainted with a modern research method since the beginning of 2020. The majority of them hail from various parts of the country. They are continuing their studies from home due to the outbreak. The first survey question aimed to determine the experience of the students with online learning. Students were asked whether they completed or have been enrolled in entirely online graduate courses. All ten students said they had been learning on an online site, whereas one student said he had done so in at least two subjects in the previous semester.

Because of the COVID-19 outbreak, not just HUFI, but also university campuses throughout the world have been forced to shutter indefinitely, and instructional activities have been relocated to online platforms. Universities needed to be well prepared for such a transformation, and their online teaching-learning process changed through time.

Table 1. Levels of experience with online learning

\begin{tabular}{|l|l|l|}
\hline Response & Count & $\%$ Student responses \\
\hline Two subjects & 2 & $20 \%$ \\
\hline Four subjects & 3 & $30 \%$ \\
\hline Five subjects & 1 & $40 \%$ \\
\hline More than Five subjects & 4 & $50 \%$ \\
\hline
\end{tabular}

\subsection{Findings for the RQ 2: Do you like studying online?}

As online learning becomes common, colleges and teachers are becoming more interested in learning about the factors that influence students' learning and satisfaction in these settings. This is especially important because data show that online courses have higher dropout rates and retention rates than traditional face-to-face courses. When asked if they like or dislike online platforms, the data obtained from the study reveals the obvious results. A few students stated that they oppose this type of education, whilst others stated that they disapproved online for various subjective and empirical factors. The research's two-item 
scale was adapted to measure students' satisfaction with online learning. Items were answered on a scale ranging from Like and Dislike. Higher scores indicated students are more dissatisfied with online learning. Positive comments from the experimental group could be mentioned to several causes. They clarified that they could save time by commuting from home every day, attend classes without wearing a uniform, sit in their rooms with some refreshments, and so on while negative comments concentrated on some objective and subjective reasons.

Table 2. Levels of satisfaction with online learning

\begin{tabular}{|l|l|l|}
\hline Response & Count & \% Student responses \\
\hline Like & 2 & $20 \%$ \\
\hline Dislike & 8 & $80 \%$ \\
\hline
\end{tabular}

\subsection{Findings for the RQ 3: What factors cause the obstacles of studying online?}

The data analysis for the third research query revealed the following information. Some characteristics of online learning related to (1) Internet connection, (2) unsuitable studying environment, (3) limited online students' feedback, (4) Less self-motivation and time management skills, (5) Lack of face-to face-communication, and (6) a bias in favor of theory.

1. Since most courses are online and dependent on high-speed internet for synchronous remote learning, varying access to broadband internet has harmed the quality of education for University students. Broadband refers to high-speed internet that is always on. According to a survey from Ho Chi Minh University of Food Industry students approximately 80 percent of students do not have access to broadband. For HUFI students overall, those in rural areas tend to have less access than those in urban areas that raises bad impacts to the constant following.

2. When community college courses moved online amid the pandemic, the shift affected student success. Classrooms, in general, are a mixture of several influences, such as classrooms, peers, and equipment..., in which students feel at ease to communicate with their professors thanks to aiding books, projectors, and whiteboards. Surroundings, on the other hand, cause them to be disturbed.

3. Teachers should have direct face-to-face input to students in conventional classes. Students who have difficulties with the program may get help easily and immediately during the lesson or the designated office hours. Students benefit from personalized input because it makes learning experiences simpler, richer, and more important while still increasing motivation. On the other hand, student input is also a problem in e-learning. When students do not get personalized input after completing daily exams, they become disappointed. Traditional methods of delivering student input do not often fit in an E-Learning world, so online education services are compelled to search for new ways to deliver feedback. The findings of this research question are to figure out how prompt feedback affects satisfaction. Feedback provides insight into a student's successful results (Chang, 2011). Brownlee et al. (2009) found that prompt feedback improves student learning experience and motivation. Students should use prompt reviews as a self- Students should use prompt reviews as a self- evaluation method to enhance their success (Rogers, 1992). The effect of feedback on future practice and student learning growth was illustrated by Eraut (2006). The effect of feedback on future practice and teachers' learning experiences will also benefit from good feedback practice (Yorke, 2003). As a result, the hypothesis that prompt feedback is essential.

4. One of the most common reasons why students struggle to complete online courses is a lack of self-motivation. Several influences in conventional classrooms continually drive students against their learning objectives. Face-to-face contact with teachers, peer-to-peer games, and tight schedules all work together to keep students on track through their studies. In certain situations, students are left to their own devices during their educational experiences, with no one constantly encouraging them to achieve their academic objectives. Students enrolled in E-Learning classes would also be expected to study complex content in the privacy of their own homes, without the additional pressures that come with conventional education. As a result, students who lack good self-motivation and time management skills can find it challenging to meet daily deadlines when studying online. The attitude of online learners also affects action motivation. Recognition and appreciation for good performance are common sources of external inspiration. It may also mean maintaining qualifications for grants, loans, or job promotions for college students. Extrinsically inspired students seek social validation and affirmation of their merit (Sansone \& Smith, 2000). Colleges typically assign points to candidates as proof that they have met the course's goals. Grades, on the other hand, are not the only or best motivator for students to succeed. College students in their late teens and early twenties have a higher extrinsic target focus, according to Jacobson (2000). This suggests that students in traditional age groups are more inspired to learn by grades than students in older age groups. External motivators, such as grades and incentives, will, on the other hand, detract from internal motivation for a mission (Deci, Koestner, \& Ryan, 1999). A student's interest in learning can be stifled if too much focus is placed on grades and incentives 
5. Many of the previously stated drawbacks of online learning are linked to the lack of face-to-face contact. A lack of face-toface contact with the teacher reduces student input, leads to social alienation, and can lead to a lack of pressure among students. A lack of pressure is a downside since it makes it easier for students to drop out of school. While many students dislike constant prodding from teachers, it is an important tool for increasing student retention.

6. At the bottom line, while some of the more advanced online learning systems are beginning to remedy and solve the internet learning flaw, the issue has yet to be fully resolved. The issue is that many Internet-learning lecturers tend to concentrate mostly (and in some cases entirely) on theoretical knowledge development rather than realistic skill's development. The explanation for this is obvious: theoretical lectures are much easier to incorporate into an online learning system than practical lectures. Since there is little face-to-face consultation and no actual classrooms to use as a workshop, conducting realistic tasks in an online course necessitates much more advanced preparation than theoretical instruction.

Table 3. Six obstacles of studying online

\begin{tabular}{|l|l|l|}
\hline Factors & Count & \% Student responses \\
\hline 1. Internet connection & 6 & $60 \%$ \\
\hline 2. Unsuitable studying environment & 4 & $40 \%$ \\
\hline 3. Limited online students' feedback & 2 & $20 \%$ \\
\hline 4. Less self-motivation and time management skills & 4 & $40 \%$ \\
\hline 5. Lack of face-to face-communication & 8 & $80 \%$ \\
\hline 6. Theoretic subjects & 2 & $20 \%$ \\
\hline
\end{tabular}

\subsection{Findings for the RQ 4: What do you expect from your online teachers?}

Expectations are a critical aspect that has a significant impact on a student's satisfaction. To assess the degree of happiness based on their assumptions, the Expectation Disconfirmation Theory (EDT) (Oliver, 1980) was used to define whether they were satisfied based on their expectations (Schwarz \& Zhu, 2015). Meeting students' aspirations is the best way to maximize their chances of achievement (Brown et al., 2014). It is possible to consider student success goals. Finally, the constructive attitude taken in many online learning courses has been shown to instil a high level of expectation in students (Gold, 2011), resulting in positive results.

As a result, the observation that the student's preferences substantially impacted satisfaction was included in this analysis. According to the findings from the HUFI interviewees, they expected two main factors from their teachers:

(1) E-Learning lesson plan design and (2) Humorous sense. The quality of a teacher's preparation becomes one of the most important things that HUFI students look for. Over half of the findings demonstrates the strong impact of E-learning lesson plan design. They explained teachers' presentations have a direct effect on their interest. They also claimed that performance with many words, colourless or impulsive, makes the online lesson plan less interesting. Furthermore, they also hoped to have more illustration images, practical activities or applied exercises during the online time. A boring E-learning lesson plan design brings ineffective results whilst observing. Many education services now tell prospective teachers that teaching is a performing art, and scholars including. It is said that using effective educational comedy in the classroom attracts an audience and is also linked to student success and achievement. In general, laughter will positively influence people's lives [...] studies have related humor to low-stress levels, high self-esteem, empathy, and interpersonal attractiveness (Merolla, 2006). Additionally, Torok, McMorris, and Lin (2004), 74 percent of college students surveyed enjoyed their professors' use of humour (p. 16). The main difference between comedy and teaching satire is that the latter is hardly original. Teachers also gather and use amusing content from other sources. As a result, lecturing with humour requires learnable skills, while comedy requires a natural sense and talent.

Table 4. Expectations of learners from their teachers

\begin{tabular}{|l|l|l|}
\hline Expectation & Count & \% Student responses \\
\hline 1. E-Learning lesson design & 6 & $60 \%$ \\
\hline 2. Humorous sense & 4 & $40 \%$ \\
\hline
\end{tabular}

\section{Recommendation and Conclusion}

During Covid-19, the investigators looked at various variables that were specifically related to students' success and result in online courses. Because of the worldwide pandemic, all colleges and universities have been forced to go online by their respective governments. Since no one knows how long the pandemic will last, the teaching process has been switched to online 
mode. Despite the fact that some educators were not tech-savvy, they revamped their skills to deal with unforeseen situations. The present study results will help the educators increase the student's satisfaction and performance in online classes. The current research assists educators in understanding the different factors that are required for online teaching. Previous studies looked at the variables that influence student satisfaction in the traditional schooling system when comparing the current study to previous research. On the other hand, the current research was conducted during HUFl's lockdown time to recognize the key factors that influence students' satisfaction with online classes. The research also looked at the relationship between student success and academic results. From the data, most HUFI students dissatisfied with online classes because of some inside and outside factors. The problems emerged students need aid-facilities to assess the internet, an appropriate space for studying without annoyance since HUFI students come from rural places. Feedback is the third element that influences student satisfaction. Instructors should take sufficient reviews after offering the course in order to schedule subsequent classes. It also aids in the formulation of prospective plans. Since feedback is the true picture of the course material, there must be a proper feedback mechanism in place for progress. Even in an online learning environment, peer-to-peer community events and online seminars that include collaboration must be included. We will guarantee that E-Learning does not fail to give students the relational skills they need to excel in real-world situations. Another form of communication in E-Learning must replace face-toface communication. Video chats, message boards, and chat rooms, for example, may help mitigate the detrimental consequences of a lack of face-to-face contact when online learning. In fact, some teachers are afraid of exposing their real images through the camera, so learners feel boring during time courses. In this case, a camera is suggested using in online classes. One of the most important approaches to improve the realistic skills of online students was to use hands-on student assignments in combination with 1:1 mentorship. On websites like Audacity and Springboard, there are many examples of popular practice-based online courses. According to another aspect of the report results, the consistency of the teacher is the most important factor that influences student satisfaction during online courses. This necessitates a high level of efficiency from the lecturer during online courses. To execute the course material effectively, teachers must first consider the psychology of the students. The student's happiness and success were affected by the teacher's ability to present the course material correctly. The teachers' viewpoint is crucial because their excitement results in a higher quality online learning experience. According to the current report, students' preferences are the second most important factor influencing their happiness during online courses. During lessons, students will have some aspirations. It is anticipated that students will do well on tests if the teacher knows the requirement and customizes his or her course design to meet the students' expectations. Style is the last aspect that influences student satisfaction. The course material should be structured in such a way that students can grasp it quickly. If the teacher designs the course to understand the material without difficulty, the students will be more satisfied, and they will do well on the tests. In certain cases, such as the practical component of the course, such as recipes for dishes or practical demonstrations in the lab, the course material is difficult to provide in online teaching. In this case, the teacher must be more innovative in planning and presenting course material to improve students' overall satisfaction with online courses. In addition, students' attentiveness also depends on their humorous sense. Online classrooms will become more connected and intimate if students can see the joy of what they are learning, or at least in their attempts to learn it. If you want to inspire your students to have more fun in class, make sure they know how to use comedy in a way that helps them achieve the course's goals. To be successful online learners, students must follow the netiquette. Despite the fact that the online style of classes was their first exposure during the Covid-19 pandemic, the students concluded that online education was beneficial to them. In order to excel in an online learning environment, you must have good self-motivation and disciplinary skills. Furthermore, online contact with professors will replace face-to-face communication, and peer-to-peer practices should be encouraged by online students in the same way they are in conventional classrooms. On the other hand, educators can see clearly the outlook in the Covid-19 pandemic with both advantages and disadvantages. Learners and teachers can avoid the risk from dangerous Coronavirus, but E-learning has caused social isolation. The latest approaches in use in education appear to cause contemplation, remoteness, and a lack of contact among students. As a result, many students and teachers who eventually spend a significant amount of time online will begin to show signs of social alienation as a result of the lack of human interaction in their lives. Lack of communication and social isolation.

In general, the findings of this study are promising in terms of the adoption of online education at Ho Chi Minh University of Food Industry because they specifically show a significant number of bachelor students' satisfaction and expectation toward the use of technology in education which brings valuable lessons for both teachers and learners. The author trusts that this study will be valuable for them.

Funding: This research received no external funding.

Conflicts of Interest: The authors declare no conflict of interest. 


\section{References}

[1] Abel, R. (2005). Implementing best practices in online learning. EDUCAUSE Quarterly, 28(3), 75-77.

[2] Brownlee, J., Walker, S., Lennox, S., Exley, B., \& Pearce, S. (2009). The first year university experience: Using personal epistemology to understsnd effective learning and teaching in higher education. Higher Education, 58(5), 599-618.

[3] Chang, N. (2011). Pre-service Teachers' views: How did E-feedback through assessment facilitate their learning? Journal of the Scholarship of Teaching and Learning, 11(2), 16-33.

[4] Deci, E. L., Koestner, R., \& Ryan, R. M. (1999). A meta-analytic review of experiments examining the effects of extrinsic rewards on intrinsic motivation. Psychological Bulletin, 125, 627-668.

[5] Drennan, J., Kennedy, J., \& Pisarski, A. (2005). Factors affecting student attitudes toward flexible online learning in management education. The Journal of Educational Research, 98(6), 331-338. doi:10.3200/JOER.98.6.331-338

[6] Eraut, M., (2006). Feedback. Learning in Health and Social Care. Volume-5, issue-3. Pg 111-118. Retrieved from https://edservices.wiley.com/how-student-feedback-creates-better-online- learning/. Accessed 23 Oct 2020.

[7] Fry, K. (2001). E-learning markets and providers: Some issues and prospects. Education+ Training, 43(4/5), 233239. https://doi.org/10.1108/EUM0000000005484. [Crossref], [Google Scholar]

[8] Gold, S. (2011). A constructivist approach to online training for online teachers. Journal of Aysnchronous Learning Networks, 5(1), 35-57.

[9] Jacobson, R. R. (2000). Differences between traditional and nontraditional students on the Motivated Strategies for Learning Questionnaire. Dissertations Abstracts International, 61 (3-A), 879.

[10] Kleinman, S. (2005). Strategies for encouraging active learning, interaction, and academic integrity in online courses. Communication Teacher, 19(1), 13-18. doi: 10.1080/1740462042000339212

[11] Kransow, J. (2013). Faculty leadership in online education: Structuring courses to impact student satisfaction and persistence. MERLOT Journal of Online Learning and Teaching, 9(1), 131-139.

[12] Merolla, A. J. (2006). Decoding ability and humor production. Communication Quarterly, 54, 175-189.

[13] M Harackiewicz (Eds.), Intrinsic and extrinsic motivation: The search for optimal motivation and performance (pp. 341-372). San Diego, CA: Academic Press.

[14] McBrien, J. L., Cheng, R., Jones, P. (2009). Virtual spaces: Employing a synchronous online classroom to facilitate student engagement in online learning. The International Review of Research in Open and Distributed Learning, 10(3), 1-17.

[15] Oliver, R. L. (1980). A congitive model of the antecedents and consequences of satisfaction decisions. JMR, Journal of Marketing Research (Pre-1986), 17(000004), 460.

[16] Palmer, S.R., \& Holt, D.M. (2009). Examining student satisfaction with wholly online learning. Journal of Computer Assisted Learning, 25(2), 101-113. doi: 10.1111/j.1365-2729.2008.00294.x

[17] Red Cross. (2020, April 21). What social distancing means. https://www.redcross.org/about-us/news-and-events/news/2020/coronaviruswhat-social-distancing-means.html [Google Scholar]

[18] Rieley, J. B. (2020). Corona Virus and its impact on higher education. Research Gate. Google Scholar

[19] Richardson, J. C., \& Swan, K. (2003). Examining social presence in online courses in relation to students' perceived learning and satisfaction. Journal of Asynchronous Learning Networks, 7(1), 68-88.

[20] Rogers, J. (1992). Adults learning (3rd ed.). Open University Press.

[21] Yorke, M. (2003). Formative assessment in higher education: Moves towards theory and the enhancement of pedagogic practice. Higher Education, 45(4), 477-501.

[22] Sansone, D., \& Smith, J.L. (2000). Interest and self-regulation: The relation between having to and want to. In Sansone \& J.

[23] Schwarz, C., \& Zhu, Z. (2015). The impact of student expectations in using instructional tools on student engagement: $A$ look through the expectation disconfirmation theory lens. Journal of Information Systems Education, 26(1), 47-58.

[24] Sener, J., \& Humbert, J. (2003). Student satisfaction with online learning: An expanding universe. Retrieved from 2003 wiki.sln.suny.edu

[25] Sinclaire, J.K. (2011). Student satisfaction with online learning: Lessons from organizational behavior. Research in Higher Education Journal, $11,1-20$.

[26] Singh, S. P., Malik, S., \& Singh, P. (2016). Factors afecting academic performance of students. ParipexIndian Journal of Research, 5(4), 176178.

[27] Torok, S. E., McMorris, R. F., \& Lin, W. (2004). Is humor an appropriate teaching tool? Perceptions of professors' teaching styles and use of humor. College Teaching, 52, 14-20.

[28] Wanzer, M. B., Frymier, A. B., \& Irwin, J. (2010). An explanation of the relationship between instructor humor and student learning: instructional humor processing theory. Communication Education, 59, 1

[29] Wang, Y-S. (2003). Assessment of learner satisfaction with asynchronous electronic learning systems. Information \& Management, 41, 75-86. doi: 101016/S0378- 7206(03)00028-4. 